\title{
Studying Impact of Different Precipitating Agents on Crystal Structure, Morphology, and Photocatalytic Activity of Bismuth Oxide
}

\author{
Yayuk Astuti ${ }^{1 *}$, Arnelli1, Pardoyo ${ }^{1}$, Amilia Fauziyah ${ }^{1}$, Siti Nurhayati ${ }^{1}$, Arum Dista \\ Wulansari ${ }^{1}$, Rizka Andianingrum ${ }^{1}$, Hendri Widiyandari ${ }^{2}$, Gaurav A. Bhaduri ${ }^{3}$ \\ ${ }^{1}$ Chemistry Department, Faculty of Science and Mathematics, Diponegoro University, Semarang, \\ Central Java, Indonesia 50275 \\ ${ }^{2}$ Department of Physics, Faculty of Science and Mathematics, Diponegoro University, Semarang, \\ Central Java, Indonesia 50275 \\ ${ }^{3}$ School of Chemical Engineering and Advanced Materials, Newcastle University, Newcastle upon \\ Tyne, United Kingdom, NE1 7RU
}

Received: 12 nd April 2017; Revised: 24th June 2017; Accepted: $12^{\text {nd }}$ July 2017; Available online: 27th October 2017; Published regularly: December 2017

\section{Abstract}

Bismuth oxide $\left(\mathrm{Bi}_{2} \mathrm{O}_{3}\right)$ is a well-studied photocatalyst for degradation of various environmental contaminants. In this research $\mathrm{Bi}_{2} \mathrm{O}_{3}$ has been synthesized by precipitation method using two different bases $\left(\mathrm{NH}_{4} \mathrm{OH}\right.$ and $\left.\mathrm{NaOH}\right)$. The samples thus obtained were then analyzed using FTIR, XRD, and SEM for surface functionalization, crystal structures and morphological differences, respectively. The $\mathrm{Bi}_{2} \mathrm{O}_{3}$ precipitated using $\mathrm{NH}_{4} \mathrm{OH}$ showed a flower like structure made up of individual plates having $\alpha-$ $\mathrm{Bi}_{2} \mathrm{O}_{3}$ crystal structure. The precipitate obtained using $\mathrm{NaOH}$ showed a honeycomb like flower structure with a mixture of both $a-\mathrm{Bi}_{2} \mathrm{O}_{3}$ and $\gamma-\mathrm{Bi}_{2} \mathrm{O}_{3}$ crystal structure. Degradation of methyl orange (MO) was used as a model system to test the photocatalytic activity of the bismuth oxide. The $\mathrm{Bi}_{2} \mathrm{O}_{3}$ synthesized using $\mathrm{NH}_{4} \mathrm{OH}$ showed superior photocatalytic degradation of methyl orange than the one synthesized using $\mathrm{NaOH}$. Copyright (C) 2017 BCREC Group. All rights reserved

Keywords: Bismuth oxide; Photocatalyst; Precipitation; Precipitating agents

How to Cite: Astuti, Y., Arnelli, Pardoyo, Fauziyah, A., Nurhayati, S., Wulansari, A.D., Andianingrum, R., Widiyandari, H., Bhaduri, G.A. (2017). Studying Impact of Different Precipitating Agents on Crystal Structure, Morphology and Photocatalytic Activity of Bismuth Oxide. Bulletin of Chemical Reaction Engineering \& Catalysis, 12 (3): 478-484 (doi:10.9767/bcrec.12.3.1144.478-484)

Permalink/DOI: https://doi.org/10.9767/bcrec.12.3.1144.478-484

\section{Introduction}

Bismuth oxide $\left(\mathrm{Bi}_{2} \mathrm{O}_{3}\right)$ is a yellow colored crystal with a melting point of $817{ }^{\circ} \mathrm{C}$ and the boiling point of $1890^{\circ} \mathrm{C}$ and insoluble in water. This material has six crystallographic polymorphs, i.e. a- $\mathrm{Bi}_{2} \mathrm{O}_{3}, \mathrm{~b}-\mathrm{Bi}_{2} \mathrm{O}_{3}, \mathrm{~g}-\mathrm{Bi}_{2} \mathrm{O}_{3}, \mathrm{~d}-\mathrm{Bi}_{2} \mathrm{O}_{3}$,

* Corresponding Author.

E-mail: yayuk.astuti@live.undip.ac.id (Astuti, Y.)

Telp.: +62-24-7460058 Fax.: +62-24-76480675 e- $\mathrm{Bi}_{2} \mathrm{O}_{3}$, and $\mathrm{w}-\mathrm{Bi}_{2} \mathrm{O}_{3}[1,2]$. The excellent optical and electrical properties like high refractive index, high dielectric permittivity and high oxygen conductivity make this material a suitable contender for various applications such as solid electrolyte fuel cells (SEFC) [3], lighting source [4], solid battery [5], photocatalyst [6], and gas sensor [7].

Chemical, structural and electrical properties of a material are dependent on its method of 
synthesis $[8,9]$. In the case of supported oxide catalyst the deposition method also plays an important role in the performance of the catalyst. The deposition method determines whether the catalyst is uniformly distributed on the support or accumulation of the oxide takes place on the areas of the support $[10,11,12]$. Therefore, various methods have been reported for synthesis $\mathrm{Bi}_{2} \mathrm{O}_{3}$ that include hydrothermal [13], direct precipitation [14-19], microwave $[6,20]$, solution combustion [21,22], and sol gel [1]. Of all these methods, described for the synthesis of $\mathrm{Bi}_{2} \mathrm{O}_{3}$ particles, the precipitation method is one of the least complex and energy efficient. Some of the most common substances used as the precipitating agents are hydroxide [14-16] and ammonia/ammonium salts $[14,17,18]$.

Zhong et al. [17] studied the use of different ammonium salt precipitants on the formation of $\mathrm{Bi}_{2} \mathrm{O}_{3}$. They do not find any change in the structural properties of the $\mathrm{Bi}_{2} \mathrm{O}_{3}$ synthesized by changing the precipitant. Rather reported that the $\mathrm{Bi}_{2} \mathrm{O}_{3}$ synthesized using $\mathrm{NH}_{3} \cdot \mathrm{H}_{2} \mathrm{O}$ showed best photocatalytic activity due to high surface area, pore volume and pore size. Therefore, in the current study we test to see if the two most commonly used precipitants (i.e. $\mathrm{NH}_{4} \mathrm{OH}$ and $\mathrm{NaOH}$ ) have an effect structural and photocatalytic properties of $\mathrm{Bi}_{2} \mathrm{O}_{3}$. Additionally we used bismuth oxy nitrate as a source of bismuth as compared to the commonly used bismuth nitrate [14-19]. The results suggested that the $\mathrm{Bi}_{2} \mathrm{O}_{3}$ synthesized using $\mathrm{NH}_{4} \mathrm{OH}$ formed $\alpha-\mathrm{Bi}_{2} \mathrm{O}_{3}$, whereas the one synthesized using $\mathrm{NaOH}$ formed a mixture of $a-\mathrm{Bi}_{2} \mathrm{O}_{3}$ and $\gamma-\mathrm{Bi}_{2} \mathrm{O}_{3}$. The photocatalytic properties of the $\mathrm{Bi}_{2} \mathrm{O}_{3}$ synthesized using $\mathrm{NH}_{4} \mathrm{OH}$ showed better activity than the $\mathrm{Bi}_{2} \mathrm{O}_{3}$ synthesized using $\mathrm{NaOH}$.

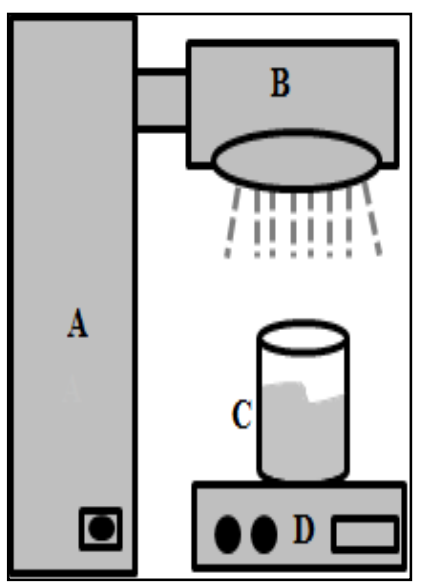

A : Lamp power supply B : Solar lamp 1000 $\mathrm{Wm}^{-2}$

$\mathrm{C}:$ Photocatalysis reactor

D : Hot plate magnetic stirrer

Figure 1. The equipment system for photocatalytic activity test

\section{Materials and Methods}

The materials used in this research were bismuth oxynitrate $\left(\mathrm{Bi}_{5} \mathrm{O}(\mathrm{OH})_{9}\left(\mathrm{NO}_{3}\right)_{4}\right)$, nitric acid $(65 \%), \mathrm{NH}_{4} \mathrm{OH}$, and $\mathrm{NaOH}$ which were purchased from Merck. The solutions were prepared in distilled water.

\subsection{Synthesis of bismuth oxide using precipitation method}

Synthesis of bismuth oxide was undertaken by mixing $10 \mathrm{~g} \mathrm{Bi} 55(\mathrm{OH})_{9}\left(\mathrm{NO}_{3}\right)_{4}$ and $20 \mathrm{~mL}$ citric acid with stirring continuously (600 rpm). When the transparent solution was obtained, subsequently the weak base $\mathrm{NH}_{4} \mathrm{OH}$ was added till the white turbid suspension with $\mathrm{pH} 9$ was formed. The precipitate obtained was then filtered and washed using distilled water and dried in an oven at $110{ }^{\circ} \mathrm{C}$ for 24 hours. The white powder was then calcined in furnace at $600{ }^{\circ} \mathrm{C}$ for 1 hour. After calcination, a yellow powder was obtained and used for further characterization. This procedure was similar to the one followed in literature [14] with slight modifications. The above procedure was repeated for synthesis of bismuth oxide with different precipitating agent by replacing $\mathrm{NH}_{4} \mathrm{OH}$ with $\mathrm{NaOH}$. In addition, the equipment system for synthesis of bismuth oxide is presented in Figure 1.

\subsection{Characterization of the samples}

The raw material bismuth subnitrate and the yellow powder were characterized using XRD (XRD Bruker with $2 \theta$ ranging from $10^{\circ}$ to $80^{\circ}$ and $\mathrm{CuKa}$ radiation $(\beta=0.15418 \mathrm{~nm})$ at 40 $\mathrm{kV}$ and $30 \mathrm{~mA}$ ), FT-IR (Prestige 21 (Shimadzu) with the wavenumber 400-4000 $\mathrm{cm}^{-1}$ ), and SEM (JEOL-JSM-G510LV) in order to identify

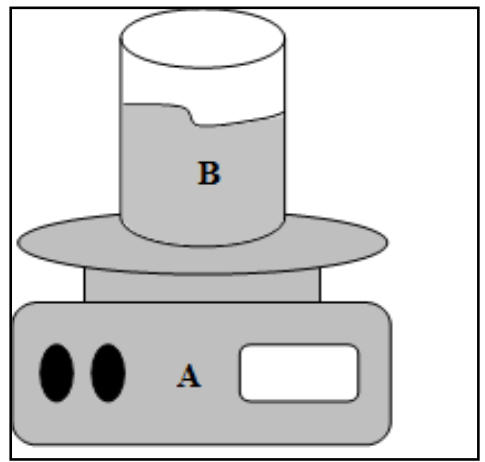

A : Hot plate magnetic stirrer B : Synthesis reactor

Figure 2. The equipment system for synthesis of bismuth oxide 
the crystal structure, the changing of functional groups, morphology and particle size, respectively.

\subsection{Photocatalytic activity test}

Photocatalytic activity of both $\mathrm{Bi}_{2} \mathrm{O}_{3}$ was tested using procedure reported previously [22]. $0.2 \mathrm{~g}$ bismuth oxide was added into 100 $\mathrm{mL}$ of 5 ppm methyl orange (MO). The mixture was irradiated using a solar simulator (PECL01, Peccell Technologies, Inc., Japan) as demonstrated in Figure 2 to simulate sunlight conditions with the powered density incident 1000 $\mathrm{Wm}^{-2}$. In order for the dye to be completely adsorbed on the surface of catalyst prior to photocatalysis, the dye and catalyst solution was stirred in dark for $30 \mathrm{~min}$. The photocatalysis experiment was carried out for 120 min under artificial solar irradiation and a sample was retrieved after every $20 \mathrm{~min}$. The retrieved reaction mixture was then centrifuged at $6000 \mathrm{rpm}$ for $5 \mathrm{~min}$ to separate the photocatalyst. The concentration of the supernatant was then measured using UV-Vis spectrophotometer at $463 \mathrm{~nm}$.

\section{Results and Discussion}

The synthesis of $\mathrm{Bi}_{2} \mathrm{O}_{3}$ by precipitation method using $\mathrm{NH}_{4} \mathrm{OH}$ and $\mathrm{NaOH}$ produced a white powder $\left(\mathrm{Bi}(\mathrm{OH})_{3}\right)$ after drying in the oven at $110^{\circ} \mathrm{C}$ for 24 hours as seen in Figure $3 \mathrm{a}$ and $3 \mathrm{~b}$, respectively. After calcination at $600{ }^{\circ} \mathrm{C}$ for $1 \mathrm{~h}$, the white powder changed its color to light yellow as seen in Figure 3c and $3 \mathrm{~d}$. The change in color indicated the formation of $\mathrm{Bi}_{2} \mathrm{O}_{3}$. As bismuth oxynitrate was used as a bismuth precursor as compared to previous reports that used bismuth nitrate [14-19], the reaction chemistry (with $\mathrm{NH}_{4} \mathrm{OH}$ ) is presented as follows:

$$
\begin{aligned}
& \mathrm{Bi}_{5} \mathrm{O}(\mathrm{OH})_{9}\left(\mathrm{NO}_{3}\right)_{4}(\mathrm{~s})+\mathrm{HNO}_{3}(\mathrm{aq}) \rightarrow \\
& 5 \mathrm{Bi}\left(\mathrm{NO}_{3}\right)_{3}(\mathrm{aq}) \\
&
\end{aligned}
$$

$4 \mathrm{Bi}(\mathrm{OH})_{3}(\mathrm{~s}) \rightarrow 2 \mathrm{Bi}_{2} \mathrm{O}_{3}(\mathrm{~s})+6 \mathrm{H}_{2} \mathrm{O}$

The XRD data for the synthesized $\mathrm{Bi}_{2} \mathrm{O}_{3}$ precipitate, using $\mathrm{NH}_{4} \mathrm{OH}$ and $\mathrm{NaOH}$, can be seen in Figure 4. When the $\mathrm{Bi}_{2} \mathrm{O}_{3}$ particles are synthesized using $\mathrm{NH}_{4} \mathrm{OH}$ (Figure 4a), they seem to be in $\mathrm{a}-\mathrm{Bi}_{2} \mathrm{O}_{3}$ phase. Iyyapushpam et al. [14] reported similar results, unfortunately no $\mathrm{pH}$ values were reported in their study. Later, Iyyapushpam et al. [15] reported the presence of $\gamma-\mathrm{Bi}_{2} \mathrm{O}_{3}$ using $\mathrm{NH}_{4} \mathrm{OH}$ at $\mathrm{pH} 9.6$
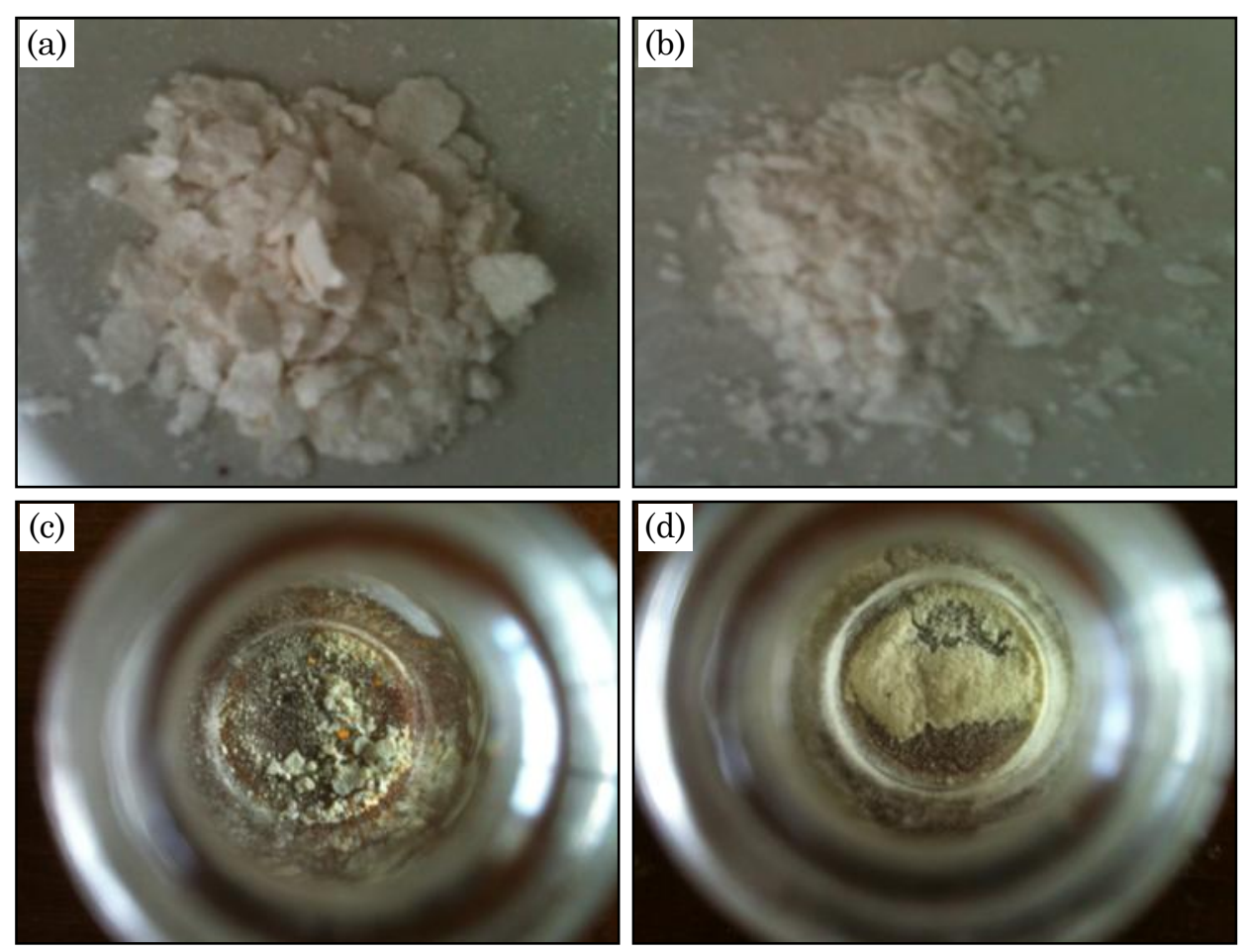

Figure 3. White product synthesized after heating the precipitate for 24 hours at $110^{\circ} \mathrm{C}$ (a) using $\mathrm{NH}_{4} \mathrm{OH}$, and (b) using $\mathrm{NaOH}$ respectively. Pale yellow precipitate formed after calcination (c) of white powder formed using $\mathrm{NH}_{4} \mathrm{OH}$, and (d) of white powder formed using $\mathrm{NaOH}$, respectively 
and their study suggests that $\mathrm{Bi}_{2} \mathrm{O}_{3}$ synthesized at $\mathrm{pH}$ below 9.6 should be in $\gamma-\mathrm{Bi}_{2} \mathrm{O}_{3}$ phase. However, in this study the resultant reaction mixture $\mathrm{pH}$ was 9 and the phase of $\mathrm{Bi}_{2} \mathrm{O}_{3}$ obtained is $\mathrm{a}-\mathrm{Bi}_{2} \mathrm{O}_{3}$. The calcination temperature used during the synthesis of $\mathrm{Bi}_{2} \mathrm{O}_{3}$ in the current study and by Iyyapushpam et al. [14] is higher than that used by Iyyapushpam et al. [15] which could be the reason for the formation of $a-\mathrm{Bi}_{2} \mathrm{O}_{3}$. It is known that $a-\mathrm{Bi}_{2} \mathrm{O}_{3}$ is a stable phase of bismuth oxide and other phases of $\mathrm{Bi}_{2} \mathrm{O}_{3}$ transform to the $\alpha-\mathrm{Bi}_{2} \mathrm{O}_{3}$ phase under high temperature $[19,23]$. This indicates that both the resultant $\mathrm{pH}$ and the calcination temperature determine the phase of $\mathrm{Bi}_{2} \mathrm{O}_{3}$.

The XRD pattern for the $\mathrm{Bi}_{2} \mathrm{O}_{3}$ synthesized using $\mathrm{NaOH}$ is presented in Figure $4 \mathrm{~b}$. The phase of the $\mathrm{Bi}_{2} \mathrm{O}_{3}$ obtained using $\mathrm{NaOH}$ has a mixture of two phases. The most intensive peak $27.2^{\circ}$ is close to the most intensive peak of both $a-\mathrm{Bi}_{2} \mathrm{O}_{3}$ and $\gamma-\mathrm{Bi}_{2} \mathrm{O}_{3}$ [19]. On comparing the diffraction patterns (a) and (b) in Figure 4, it can be seen that there are two additional peaks in pattern (b) (marked with asterisk) that correspond to $\gamma-\mathrm{Bi}_{2} \mathrm{O}_{3}[19]$. This suggests that the material synthesized using $\mathrm{NaOH}$ is a mixture of both $a-\mathrm{Bi}_{2} \mathrm{O}_{3}$ and $\gamma-\mathrm{Bi}_{2} \mathrm{O}_{3}$, where $a-\mathrm{Bi}_{2} \mathrm{O}_{3}$ is the most dominant phase as seen from Figure 4b. Combining the results of this study with the previous study of Iyyapushpam et al. [14] suggests that during calcification the $\mathrm{Bi}_{2} \mathrm{O}_{3}$ first $\gamma-\mathrm{Bi}_{2} \mathrm{O}_{3}$ phase is formed and then it transforms into $\alpha-\mathrm{Bi}_{2} \mathrm{O}_{3}$ phase. Therefore, the desired phase of $\mathrm{Bi}_{2} \mathrm{O}_{3}$ synthesized using precipitation method can be synthesized by regulating the calcification temperature alone.

FTIR spectra of $\mathrm{Bi}_{2} \mathrm{O}_{3}$ synthesized by precipitation method using $\mathrm{NH}_{4} \mathrm{OH}$ and $\mathrm{NaOH}$ can

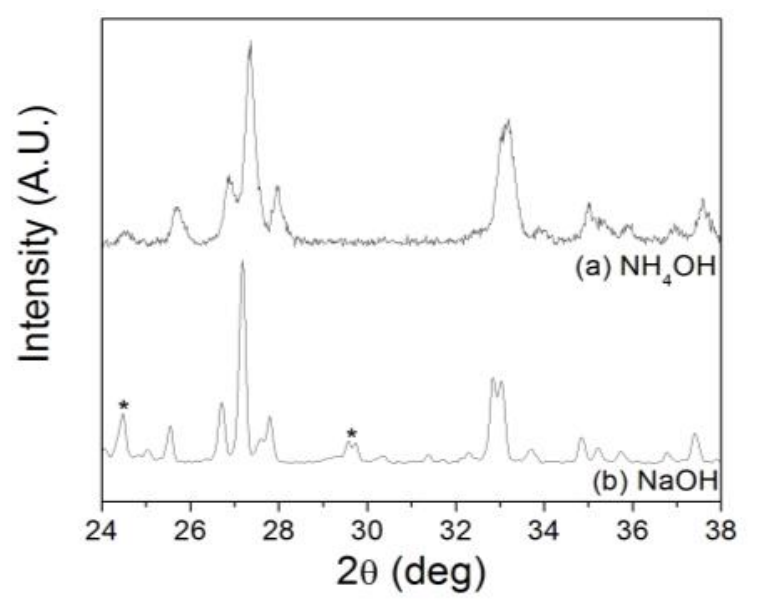

Figure 4. X-ray diffraction of bismuth oxide synthesized using (a) $\mathrm{NH}_{4} \mathrm{OH}$ and (b) $\mathrm{NaOH}$ precipitating agents, respectively be seen in Figure 5. The FTIR of the starting material (see Ref. [22]) shows sharp and intense vibration band at $1200-1700 \mathrm{~cm}^{-1}$ indicating the presence of nitrate $\left(\mathrm{NO}_{3}\right)$ and has been discussed previously [22]. Peaks observed between $3200-3600 \mathrm{~cm}^{-1}$ indicate the presence of $\mathrm{OH}$ groups [24,25]. The absence of dominant peaks between $1200-1700 \mathrm{~cm}^{-1}$ and $3200-3600$ $\mathrm{cm}^{-1}$ in Figure 5 indicate the absence of both nitrate and hydroxide groups on the $\mathrm{Bi}_{2} \mathrm{O}_{3}$ surface. Moreover, the observed vibrational band between wavenumber 700-600 $\mathrm{cm}^{-1}$ and at $\sim 830 \mathrm{~cm}^{-1}$ can be assigned to $\mathrm{Bi}-\mathrm{O}-\mathrm{Bi}$ vibration [24-27].

The SEM images of the $\mathrm{Bi}_{2} \mathrm{O}_{3}$ synthesized using $\mathrm{NH}_{4} \mathrm{OH}$ show small plate like structures arranged in the flower like manner as seen in Figure 6a. It can be seen the flower like structure is made up of individual plate like structures having a thickness of $\sim 20 \pm 10 \mathrm{~nm}$. Duan et al. [28] synthesized similar flower like structures using bismuth oxide formate. Alternatively, the $\mathrm{Bi}_{2} \mathrm{O}_{3}$ synthesized using $\mathrm{NaOH}$ has a honeycomb like flower structure as presented in Figure 6b. Previously, Zhou et al. [9] synthesized similar flower like structure using $\mathrm{VO}_{3}$ as a precursor to get the desired shape of $\mathrm{Bi}_{2} \mathrm{O}_{3}$ particles. Comparing Figure $6 \mathrm{a}$ and $6 \mathrm{~b}$ it can be seen that the sheets of $\mathrm{Bi}_{2} \mathrm{O}_{3}$ particles synthesized using $\mathrm{NH}_{4} \mathrm{OH}$ are thicker than that of the particles synthesized using $\mathrm{NaOH}$. As compared to the Figure 6a the particles in Figure $6 \mathrm{~b}$ show a densely packed porous structure, having pore of 500-800 $\mathrm{nm}$.

The photocatalytic activity of the synthesized $\mathrm{Bi}_{2} \mathrm{O}_{3}$ particles was evaluated by studying the degradation of aqueous solution of methyl orange under artificial solar irradia-

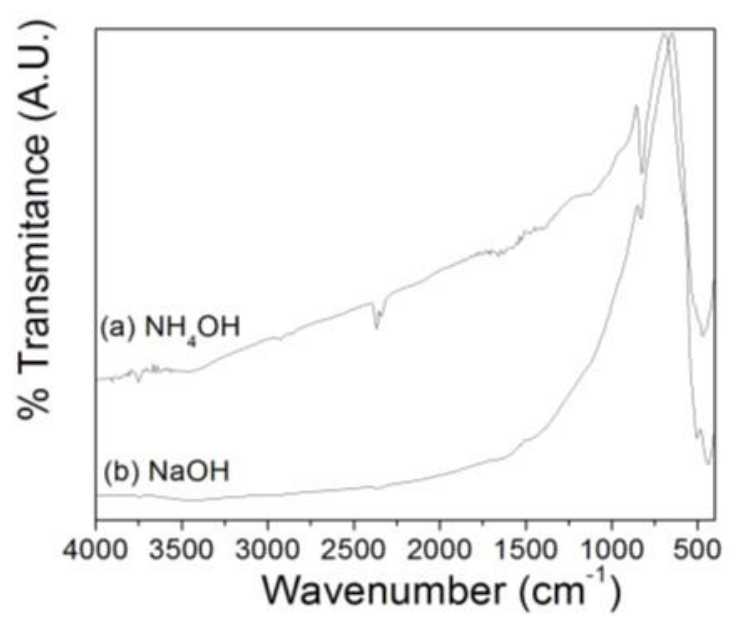

Figure 5. FTIR spectra of the $\mathrm{Bi}_{2} \mathrm{O}_{3}$ synthesized using (a) $\mathrm{NH}_{4} \mathrm{OH}$ and (b) $\mathrm{NaOH}$, respectively 
tion. Figure $7 \mathrm{a}$ shows the photodegradation efficiency of methyl orange in absence and presence of the two flower like $\mathrm{Bi}_{2} \mathrm{O}_{3}$ synthesized using $\mathrm{NaOH}$ and $\mathrm{NH}_{4} \mathrm{OH}$, respectively, as a function of irradiation time. It can be seen that there was $\sim 64 \%$ degradation of methyl orange in the presence of $\mathrm{Bi}_{2} \mathrm{O}_{3}$ synthesized using $\mathrm{NaOH}$ as compared to $78 \%$ degradation of methyl orange in presence of $\mathrm{Bi}_{2} \mathrm{O}_{3}$ synthesized using $\mathrm{NH}_{4} \mathrm{OH}$ in 120 min.

The kinetic evaluation of the photocatalyst was carried out by using the LangmuirHinshelwood model, for pseudo-first order kinetics given by the Equation (1) [14,15,29].

$$
-\ln \frac{C}{C_{0}}=k t
$$

where, $C_{o}$ is the initial concentration of methyl orange, $C$ is the concentration of methyl orange at different irradiation time, $k$ is the kinetic constant of the reaction, and $t$ is the irradiation time. Figure $7 \mathrm{~b}$ shows the linear plot of - $\ln \left(C / C_{0}\right)$ vs $t$ for the two flower like $\mathrm{Bi}_{2} \mathrm{O}_{3}$ catalysts, respectively. It can be seen from the Figure $7 \mathrm{~b}$ that the $\mathrm{Bi}_{2} \mathrm{O}_{3}$ synthesized using $\mathrm{NH}_{4} \mathrm{OH}$ had a higher kinetic rate constant of $12.5 \times 10^{-3} \mathrm{~s}^{-1}$ as compared to $\mathrm{Bi}_{2} \mathrm{O}_{3}$ synthesized using $\mathrm{NaOH}$ of $8.8 \times 10^{-3} \mathrm{~s}^{-1}$. The kinetic rate constant of the $\mathrm{Bi}_{2} \mathrm{O}_{3}$ synthesized using $\mathrm{NH}_{4} \mathrm{OH}$ was greater than that previously reported by Iyyapushpam et al. [14]. The reasons for the lower activity of $\mathrm{Bi}_{2} \mathrm{O}_{3}$ synthesized using $\mathrm{NaOH}$ is the presence of the partial $\gamma-\mathrm{Bi}_{2} \mathrm{O}_{3}$ phase. It is known that the $\gamma-\mathrm{Bi}_{2} \mathrm{O}_{3}$ has lower activity (about one order of magnitude) than that of $\alpha-\mathrm{Bi}_{2} \mathrm{O}_{3}[14,15]$. The catalytic activity of the $\mathrm{Bi}_{2} \mathrm{O}_{3}$ synthesized using $\mathrm{NaOH}$ had a higher activity than that of pure $\gamma-\mathrm{Bi}_{2} \mathrm{O}_{3}$ of $3.3 \times 10^{-4} \mathrm{~s}^{-1}$ [15] and $1.1 \times 10^{-4} \mathrm{~s}^{-1}[6]$.

\section{Conclusions}

Synthesis of $\mathrm{Bi}_{2} \mathrm{O}_{3}$ using the precipitation method with different precipitating agents was studied. The use weak base $\left(\mathrm{NH}_{4} \mathrm{OH}\right)$ for $\mathrm{Bi}_{2} \mathrm{O}_{3}$ precipitation resulted in formation of plate
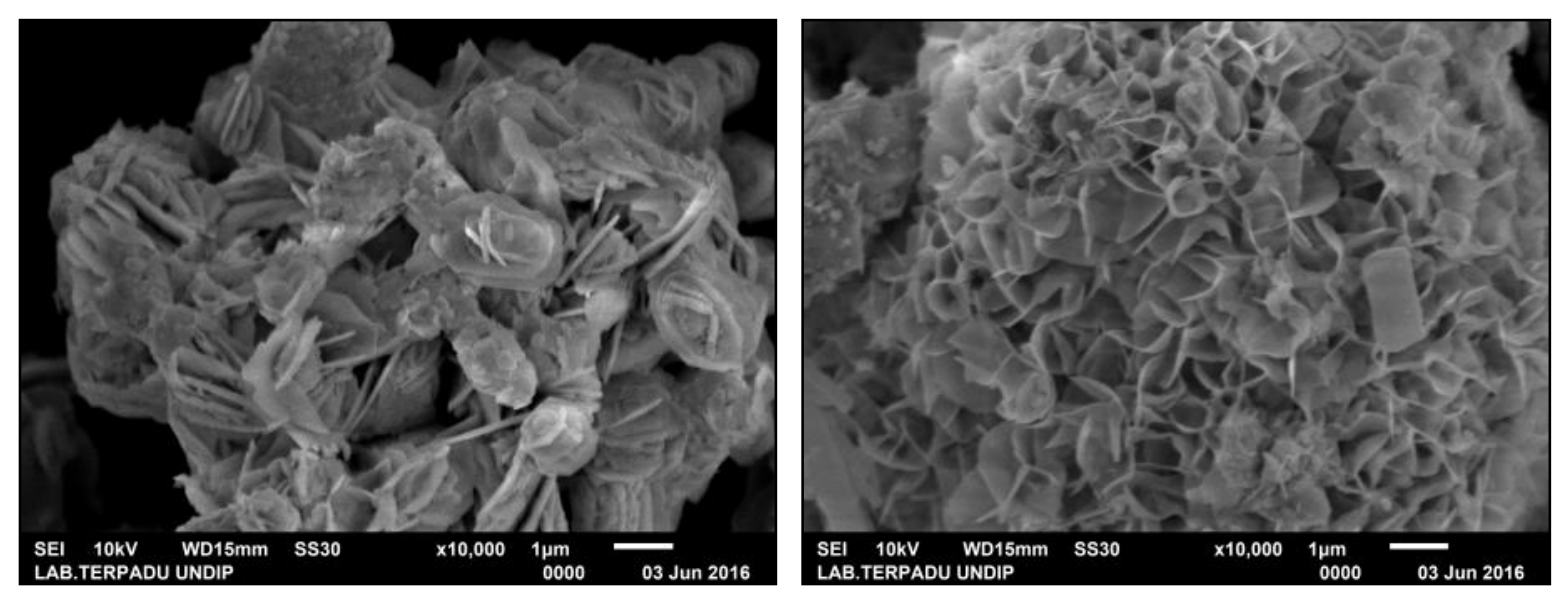

Figure 6. SEM images of bismuth oxide synthesized using (a) $\mathrm{NH}_{4} \mathrm{OH}$ and (b) $\mathrm{NaOH}$, respectively
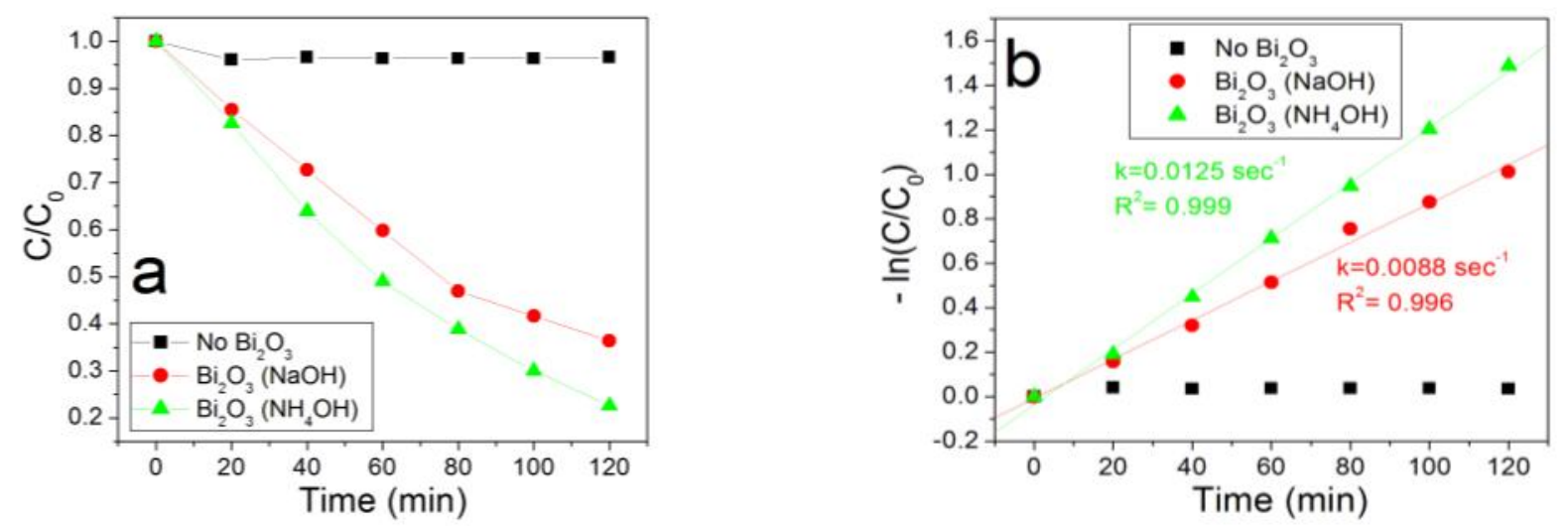

Figure 7. (a) Photodegradation of methyl orange in presence and absence of $\mathrm{Bi}_{2} \mathrm{O}_{3}$, and (b) kinetic linear simulation curves of the degradation of methyl orange in presence of $\mathrm{Bi}_{2} \mathrm{O}_{3}$ particles synthesized using $\mathrm{NaOH}$ and $\mathrm{NH}_{4} \mathrm{OH}$, respectively. 
type structures arranged in the form of flowers. The use of strong base $(\mathrm{NaOH})$ for precipitation of $\mathrm{Bi}_{2} \mathrm{O}_{3}$ led to formation of honeycomb like flower structure. Moreover, the photocatalytic activity of $\mathrm{Bi}_{2} \mathrm{O}_{3}$ synthesized using $\mathrm{NH}_{4} \mathrm{OH}$ had better activity on degradation of methyl orange than the $\mathrm{Bi}_{2} \mathrm{O}_{3}$ synthesized using $\mathrm{NaOH}$. The activity was dependent on the crystal structure of the $\mathrm{Bi}_{2} \mathrm{O}_{3}$.

\section{Acknowledgement}

The authors wish to acknowledge Faculty of Science and Mathematics, Diponegoro University for financial support with grant no. 3045/UN7.3.8/PG/2015, the Integrated Laboratory, Diponegoro University for XRD and SEM analysis and Laboratory of Organic Chemistry, Gajah Mada University for FTIR analysis.

\section{References}

[1] Mallahi, M., Shokuhfar, A., Vaezi, M.R., Esmaeilirad, A., Mazinani, V. (2014). Synthesis and Characterization of Bismuth Oxide Nanoparticles via Sol-Gel Method. American Journal of Engineering Research, 03: 162-165.

[2] Gomez, C.L., Depablos-Rivera, O., SilvaBermudez, P., Muhl, S., Zeinert, A., Lejeune, M., Charvet, S., Barroy, P., Camps, E., Rodil, S.E. (2015). Opto-electronic Properties of Bismuth Oxide Films Presenting Different Crystallographic Phases. Thin Solid Films, 578: 103-112.

[3] Lee, J.G., Kim, S.H., Yoon, H.H. (2011). Synthesis of Yttria-Doped Bismuth Oxide Powder by Carbonate Coprecipitation for IT-SOFC Electrolyte. Journal of Nanoscience and Nanotechnology, 11(1): 820-823.

[4] Chu, Y.-C., Lee, G.J., Chen, C.Y., Ma, S.H., Wu, J.J., Horng, T.L., Chen, K.H. and Chen, J.H. (2013). Preparation of Bismuth Oxide Photocatalyst and Its Application in Whitelight LEDs. Journal of Nanomaterials, 2013: 1-7.

[5] Li, Y., Trujillo, M.A., Fu, E., Patterson, B., Fei, L., Xu, Y., Deng, S., Smirnov, S., Luo, H. (2013). Bismuth Oxide: A New Lithium-Ion Battery Anode. Journal of Materials Chemistry A, 1(39): 12123-12127.

[6] Liu, X., Pan, L., Lv, T., Sun, Z., Sun, C.Q. (2013). Visible Light Photocatalytic Degradation of Dyes by Bismuth Oxide-Reduced Graphene Oxide Composites Prepared via Microwave-Assisted Method. Journal of Colloid and Interface Science, 408: 145-150.

[7] Martirosyan, K.S., Wang, L., Vicent, A., Luss D. (2009). Synthesis and Performance of Bis- muth Trioxide Nanoparticles for High Energy Gas Generator Use. Nanotechnology, 20(40): $1-8$.

[8] Gotić, M., Popović, S., Musić, S. (2007). Influence of Synthesis Procedure on the Morphology of Bismuth Oxide Particles. Materials Letters, 61(3): 709-714.

[9] Zhou, L., Wang, W., Xu, H., Sun, S., Shang, M. (2009). $\mathrm{Bi}_{2} \mathrm{O}_{3}$ Hierarchical Nanostructures: Controllable Synthesis, Growth Mechanism, and their Application in Photocatalysis. Chemistry - A European Journal, 15(7): 17761782.

[10] Rubel, M.H.K., Miura, A., Takei, T., Kumada, N., Ali, M.M., Nagao, M., Watauchi, S., Tanaka, I., Oka, K., Azuma, M. (2014). Superconducting Double Perovskite Bismuth Oxide Prepared by a Low-Temperature Hydrothermal Reaction. Angewandte Chemie International Edition, 53(14): 3599-3603.

[11] Sarli, D.V., Landi, G., Lisi L., Saliva, A., Di Benedetto, A. (2016). Catalytic Diesel Particulate Filters with Highly Dispersed Ceria: Effect of the Soot-Catalyst Contact on the Regeneration Performance. Applied Catalysis B: Environmental, 197:116-124.

[12] Sarli, V.D., Landi, G., Lisi, L. (2017). CeriaCoated Diesel Particulate Filters for Continuous Regeneration. AlChE Journal, AIChE Journal, 63(8): 3442-3449.

[13] Pérez, V.R., Bueno-López A. (2015). Catalytic Regeneration of Diesel Particulate Filters: Comparison of $\mathrm{Pt}$ and $\mathrm{CePr}$ Active Phases. Chemical Engineering Journal, 279: 79-85.

[14] Iyyapushpam, S., Nishanthi, S.T., Padiyan, D.P. (2013). Photocatalytic Degradation of Methyl Orange Using a- $\mathrm{Bi}_{2} \mathrm{O}_{3}$ Prepared without Surfactant. Journal of Alloys and Compounds, 563: 104-107.

[15] Iyyapushpam, S., Nishanthi, S.T., Padiyan, D.P. (2014). Enhanced Photocatalytic Degradation of Methyl Orange by Gamma $\mathrm{Bi}_{2} \mathrm{O}_{3}$ and Its Kinetics. Journal of Alloys and Compounds, 601: 85-87.

[16] López-Salinas, F.I., Martínez-Castañón, G.A., Martínez-Mendoza, J.R., Facundo Ruiz. (2010). Synthesis and Characterization of Nanostructured Powders of $\mathrm{Bi}_{2} \mathrm{O}_{3}, \mathrm{BiOCl}$ and Bi. Materials Letters, 64(14): 1555-1558.

[17] Zhong, J.B., Zeng, J., Li, J.Z., Hu, W. (2011). Photocatalytic Activity of $\mathrm{Bi}_{2} \mathrm{O}_{3}$ Prepared by Different Precipitants. Advanced Materials Research, 239-242: 998-1001.

[18] Lu, Y., He, X.Y., Zhong, J.B., Li, J.Z., Hu, W. (2012). Photocatalytic Activity of $\mathrm{Bi}_{2} \mathrm{O}_{3}$ Prepared by Different $\mathrm{pH}$ Value. Advanced Materials Research, 418-420: 554-557. 
[19] Tseng, T.-K., Choi, J., Jung, D-W., Davidson, M., Holloway, P.H. (2010). Three-Dimensional Self-Assembled Hierarchical Architectures of Gamma-Phase Flowerlike Bismuth Oxide. ACS Applied Materials \& Interfaces, 2(4): 943-946.

[20] Bartonickova, E., Cihlar, J., Castkova, K. (2007). Microwave-assisted Synthesis of Bismuth Oxide. Processing and Application of Ceramics, 1(1-2): 29-33.

[21] La, J., Huang, Y., Luo G., Lai, J., Liu, C., Chu, G. (2013). Synthesis of Bismuth Oxide Nanoparticles by Solution Combustion Method. Particulate Science and Technology, 31(3): 287-290.

[22] Astuti, Y., Fauziyah, A., Nurhayati, S., Wulansari, A.D., Andianingrum, R., Hakim, A.R., Bhaduri, G. (2016). Synthesis of a-Bismuth Oxide Using Solution Combustion Method and Its Photocatalytic Properties. IOP Conference Series: Materials Science and Engineering, 107(1): 1-7.

[23] Mehring, M. (2007). From Molecules to Bismuth Oxide-Based Materials: Potential Homo- and Heterometallic Precursors and Model Compounds. Coordination Chemistry Reviews, 251(7-8): 974-1006.
[24] Hu, Y., Liu, N.-H., Lin, U.-L. (1998). Glass Formation and Glass Structure of the $\mathrm{BiO}_{1.5^{-}}$ $\mathrm{PbO}-\mathrm{CuO}$ System. Journal of Materials Science, 33(1): 229-234.

[25] Narang, S.N., Patel, N.D., Kartha, V.B. (1994). Infrared and Raman Spectral Studies and Normal Modes of $a-\mathrm{Bi}_{2} \mathrm{O}_{3}$. Journal of $\mathrm{Mo}$ lecular Structure, 327(2): 221-235.

[26] Iordanova, R., Dimitriev, Y., Dimitrov, V., Kassabov, S., Klissurski, D. (1996). Glass Formation and Structure in the $\mathrm{V}_{2} \mathrm{O}_{5}-\mathrm{Bi}_{2} \mathrm{O}_{3}$ $\mathrm{Fe}_{2} \mathrm{O}_{3}$ Glasses. Journal of Non-Crystalline Solids, 204(2): 141-150.

[27] Iordanova, R., Dimitrov, V., Dimitriev, Y., Klissurski, D. (1994). Glass Formation and Structure of Glasses in the $\mathrm{V}_{2} \mathrm{O}_{5}-\mathrm{MoO}_{3}-\mathrm{Bi}_{2} \mathrm{O}_{3}$ System. Journal of Non-Crystalline Solids, 180(1): 58-65.

[28] Duan, F., Zheng, Y., Liu, L., Chen, M., Xie, Y. (2010). Synthesis and Photocatalytic Behaviour of 3D Flowerlike Bismuth Oxide Formate Architectures. Materials Letters, 64(14): 1566-1569.

[29] Yang, L.-L., Han, Q-F, Zhao, J., Zhu, J-W., Wang, X., Ma, W-H. (2014). Synthesis of $\mathrm{Bi}_{2} \mathrm{O}_{3}$ Architectures in DMF- $\mathrm{H}_{2} \mathrm{O}$ Solution by Precipitation Method and their Photocatalytic Activity. Journal of Alloys and Compounds, 614: 353-359. 